\title{
Special Issue in Honor of Dr. Graham A. R. Johnston
}

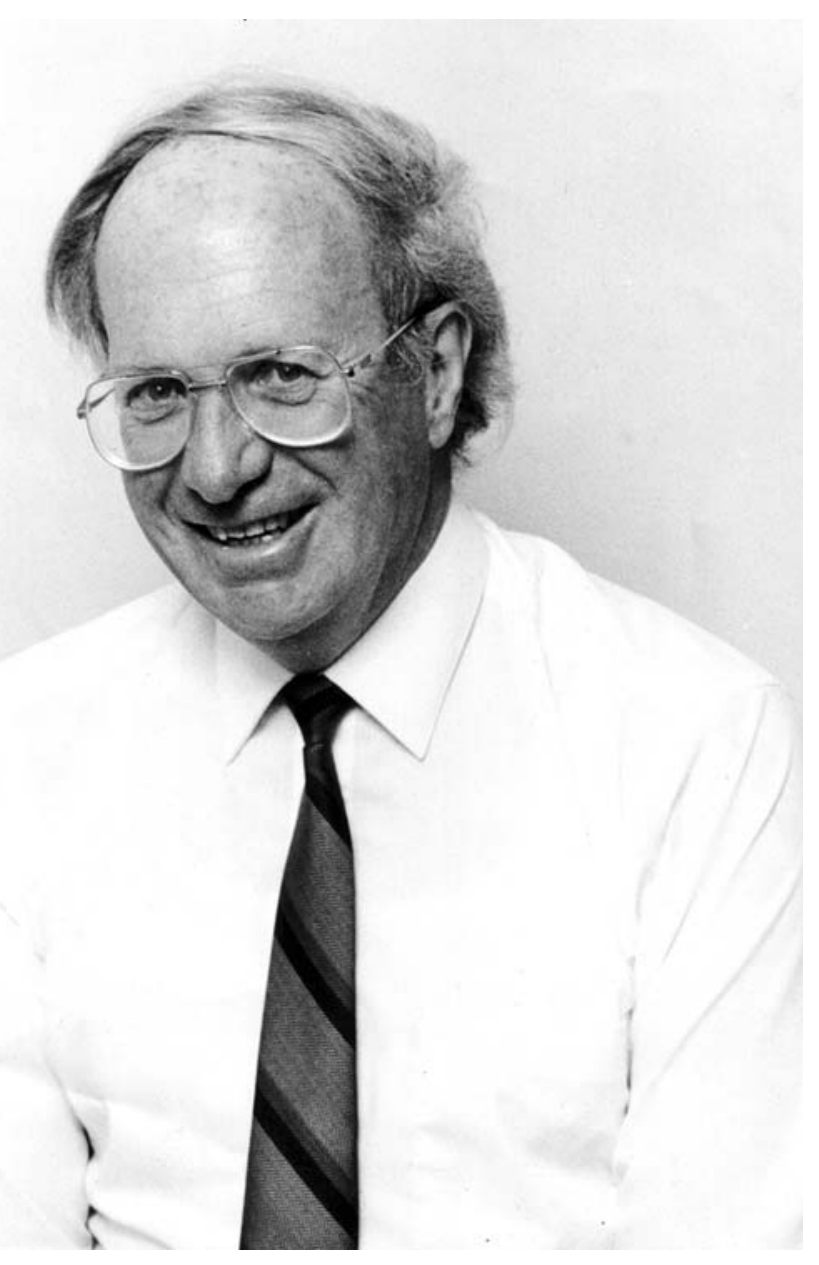

Dr. Graham A. R. Johnston

Philip M. Beart, Vladimir J. Balcar Guest Editors 